\title{
Enkapsülasyon Teknikleri ve Kontrollü Salım
}

\author{
Özlem Aydın ${ }^{1 *}$, İsmigül Ünlüel ${ }^{2}$ \\ ${ }^{1 *}$ Kırşehir Ahi Evran Üniversitesi, Mühendislik-Mimarlık Fakültesi, Gıda Mühendisliği Bölümü, Kırşehir, Türkiye, (ORCID: 0000-0002-5645-3792), \\ ozlem.aydin@ahievran.edu.tr \\ 2 Kırşehir Ahi Evran Üniversitesi, Mühendislik-Mimarlık Fakültesi, Gıda Mühendisliği Bölümü, Kırşehir, Türkiye (ORCID: 0000-0002-3097-5365), \\ ismiguul@gmail.com
}

(International Conference on Design, Research and Development (RDCONF) 2021 - 15-18 December 2021)

(DOI: 10.31590/ejosat.1039736)

\begin{abstract}
ATIF/REFERENCE: Aydın, Ö. \& Ünlüel, İ. (2021). Enkapsülasyon Teknikleri ve Kontrollü Salım. Avrupa Bilim ve Teknoloji Dergisi, (32), 640-648.

\section{Öz}

Enkapsülasyon, en az bir aktif bileşenin en az bir çeşit kaplama materyali tarafından uygun koşullarda ve istenilen dozda salınması koşuluyla koruma altına alınmasıdır. Kullanılacak malzemenin biyouyumlu ve biyobozunur olması yanı sıra aktif bileşenin stabilitesini sağlıyor olması da gereklidir. Kontrollü salım sistemleri; gelişmiş etkinlik, enkapsüle veya immobilize edilmiş bileşenlerin enzimatik vb. degradasyonuna karşı yüksek stabiliteye sahip olması, azaltılmış toksisite, kolay uygulama gibi sayısız avantajlara sahiptirler. Salım sistemlerinin formu küre, kapsül, çubuk, membran, slab gibi farklı biçimlerde olabilmektedir. Boyutları ise kullanım amacı sebebiyle farklı ölçülerde olabilmekte; nano, mikro veya mili seviyeler arasında değişebilmektedir. Genel olarak mikro- ve nanoparçacıklar olarak isimlendirilen bu formlar; ilaçlar, vitaminler, mineraller, uçucu aromatik bileşikler ve nutrasötik olarak adlandırılan çeşitli besin takviyeleri gibi aktif bileşenlerin taşıyıcısı olabilmektedirler. Enkapsülasyonda asıl hedef hassas bileşenlerin korunması ve zamanla ayarlanan ölçüde salınmasıdır. Mikro veya nanopartiküller içindeki aktif maddelerin enkapsülasyonu için yaygın olarak kullanılan farklı teknikler mevcuttur. Bunlar; termal faz ayırma (koaservasyon), sprey soğutma ve dondurma, eriyik dağılımı, çözücü buharlaşması, akışkan yatak kaplaması, sprey kurutma, su ve organik fazların homojenizasyonu, dönel süspansiyon ayırma, ekstrüzyon ve inklüzyon kompleksi vb. tekniklerdir. Bu derlemenin amac1 farklı enkapsülasyon teknikleri ile aktif bileşenlerin kontrollü salımı hakkında genel bilgiler vermektir.
\end{abstract}

Anahtar Kelimeler: Kontrollü salım, Enkapsülasyon, Aktif bileşen.

\section{Encapsulation Techniques and Controlled Release}

\begin{abstract}
Encapsulation is the protection of at least one active ingredient by at least one kind of coating material, provided that it is released under appropriate conditions and at the desired dose. The used material must be biocompatible and biodegradable, as well as ensuring the stability of the active ingredient. Controlled release systems have numerous advantages; such as, enhanced efficacy, high stability against enzymatic etc. degradation of encapsulated or immobilized components, reduced toxicity, and easy application. The release systems can be in different forms such as sphere, capsule, rod, membrane, slab, etc. Its dimensions, on the other hand, can be of different sizes due to the purpose of use; it can vary between nano, micro or milli levels. These forms, which are generally called micro- and nanoparticles; can be carriers of active ingredients such as drugs, vitamins, minerals, volatile aromatic compounds and various nutritional supplements called nutraceuticals. The main goal in encapsulation is the preservation of sensitive components and their release over time to a set extent. There are different techniques commonly used for the encapsulation of active substances into micro or nanoparticles. These are the techniques; thermal phase separation (coacervation), spray cooling and freezing, melt dispersion, solvent evaporation, fluidized bed coating, spray drying, homogenization of water and organic phases, rotary suspension separation, extrusion and inclusion complex, etc. The aim of this review is to give general information about the controlled release of active ingredients with different encapsulation techniques.
\end{abstract}

Keywords: Controlled release, Encapsulation, Active substance.

\footnotetext{
*Sorumlu Yazar: ozlem.aydin@ahievran.edu.tr
} 


\section{Giriş}

Kontrollü salım sistemlerinin eczacılık, gıda, kimya, ziraat gibi alanlarda özellikle 1980'li yıllardan itibaren hızla yaygınlaştığı görülmektedir. Enkapsülasyon, çevreye duyarlı hassas bileşenleri korur ve aktif maddelerin zamanla salınmasını sağlar. Bazı bileşenlerin enkapsüle edilmesi kolaydır. Ancak bazı hassas bileşenlerin enkapsülasyonu çok zordur, bu nedenle kontrollü koruma ve salım gereklidir.

Enkapsülasyon, en az bir aktif bileşenin en az bir çeşit kaplama materyali tarafindan çeşitli teknikler kullanılarak koruma altına alınmasıdır. Aktif bileşenin uygun koşullarda ve istenilen dozda salınması amacına dayanan bu işlemde, aktif bileşenin hangi malzeme kullanılarak hangi yöntemle kaplanacağı önemlidir. Kullanılacak malzemenin biyouyumlu ve biyobozunur olması yanı sıra aktif bileşenin stabil kalması gereklidir. Genel olarak mikro- ve nanoparçacıklar olarak isimlendirilen bu formlar çok çeşitli özellikte hidrofilik veya hidrofobik ilaçlar, vitaminler, mineraller ve farklı besinler gibi aktif bileşenlerin taşıyıcısı olmaktadırlar.

Kontrollü salım teknolojisinden en çok faydalanan bilim dalı farmakoloji olup, ilaçlar farklı yöntemlerle enkapsüle edilmektedir. İlaç salım sistemleri kullanılan ilacın yan etkilerini ortadan kaldırmak, hedeflenen doku dışında başka bölgelere gitmesini önlemek, ilacın stabilitesini korumak ve kan dolaşımı olmayan bölgelere ilacın ulaşmasını sağlamak için tercih edilirler. Ayrıca ilacın kandaki seviyesinin tedavi boyunca aynı düzeyde tutulmasına olanak sağladığından, ortaya çıkabilecek değişimlerin ve olumsuzlukların önlenmesi sağlanmaktadır. Gıda bileşenleri, probiyotikler, aroma bileşenleri gibi özellikle yapıları çabuk bozulmaya yatkın bileşenler de koruma amacıyla enkapsüle edilmektedir.

\section{Kontrollü Salım Sistemleri}

Kontrollü salım sistemleri; gelişmiş etkinlik, enkapsüle veya immobilize edilmiş bileşenlerin enzimatik-enzimatik olmayan, fiziksel, kimyasal değişimlerine ve degradasyonuna karşı yüksek stabiliteye sahip olması, azaltılmış toksisite, kolay uygulama gibi sayısız avantajlara sahiptirler. (Feng vd., 2004; Kumar vd., 2004; Langer, 2001; Mu \& Feng, 2003; Ratnam vd., 2006). Polimerler aktif bileşenlerin taşıyıcısı olarak eczacılık ve gida endüstrisinde yaygın olarak tercih edilmektedir (Legrand vd., 1999). En başarılı enkapsülasyonun sağlandığı polimerler, poliesterler, polisakkaridler vb.'dir. Aktif bileşenlerin kontrollü salımı, enkapsüle veya immobilize materyalin performansını biyolojik aktivite ya da kabul edilebilir degradasyon ürünlerinin aktivitesi olarak korumayı gerektirmektedir (Besenbache vd., 2007; Moghimi vd., 2005; Sahoo vd., 2007; Stevanovic' \& Uskokovic', 2009a,b; Sumer \& Gao, 2008; Wong vd., 2007). Kontrollü salım için, biyobozunur ve biyoaşınır polimerler bu materyallerin en önemli çeşidini temsil etmektedir. Bunlar, Dünya Sağlık Örgütü (WHO) ve Gıda ve İlaç Dairesi (FDA) tarafindan ilaç ve tedavi amaçlı kullanım için onaylanmış polimerlerdir. İlaç iletim çalışmalarında genellikle güvenli olarak kabul edilen (GRAS) polimerler kullanılır. Gıda ve İlaç İdaresi (FDA), klinik çalışmalarda sınırlı sayıda polimerin kullanımını onaylamıştır.

Eczacılık, tıp ve gıda endüstrilerinde enkapsülasyon ve immobilizasyon teknikleri yaygın olarak kullanılmaktadır. Vitamin ve diğer aktif bileşenler mükemmel işleme özelliği, biyouyumluluğu ve amaçlanan uygulama için uyarlanabilecek oranlarda biyolojik bozunma potansiyeline sahip olan polyester ve polisakkaridlere başarıyla enkapsüle edilebilmektedir. Mikrove nanoparçacıklar çok çeşitli sayıda aktif bileşenler için, örneğin hidrofilik veya hidrofobik ilaçlar, vitaminler, mineraller ve farklı besinler vb. taşıyıcı olarak kullanılabilirler. Her birinin vücuda alım şekli farklıdır. Polisakkaridler, lipozomlar, sentetik polimerler vb. gibi çeşitli malzemelerden üretilirler. Taşıyıcıların doğası ve matriksi çok çeşitli malzemelerden, örneğin polisakkaridler, liposomlar, sentetik polimerler arasından genel olarak güvenilir (GRAS) farmasötik veya gıda endüstrisi malzeme listesi arasından uygulamanın ihtiyaçlarını hem de düzenleyici talepleri karşılayacak şekilde (örneğin biyobozunurluk) seçilir. (D’Emanuele vd., 2004; Kozubek vd., 2001; Lian \& Ho, 2001; Liu \& Frechet, 1999; Medina vd., 2004; Nafee vd., 2007; Stevanovic' vd., 2007a,b; Yoo, 2006; Rados, 2004).

Kontrollü salım formülasyonlarından biyoaktif maddelerin salımında üç mekanizma vardır: "Polimer matrisinden Fick difüzyonu, matriksteki gözenekler yoluyla difüzyon ve polimer erozyonu ile ilaçların serbest bırakılması" (Jeong vd., 2003). Burada Fick difüzyonu olarak bilinen 1855 yılında Adolf Fick tarafından belirlenmiş Fick'in difüzyon yasaları difüzyonu tanımlar ve bu da Fick Kanunu adıyla literatürde yer almaktadır. Ancak kontrollü salım formülasyonları, sistemle ilgili birkaç faktöre daha (polimer ve ilaç özellikleri ve oranları, büyüklüğü ve şekli) bağlı olduğundan bunlar için genel bir salım profili sağlamak zordur. Polimerle ilgili faktörler moleküler ağırlık, kristallik ve hidrofilik olma vb.'dir. Aktif bileşen olarak en çok kullanılan ilaç olduğundan, ilaca bağlı olan faktörler ise ilacın çözünürlüğü, moleküler ağırlıktaki polimer-ilaç etkileşimleri, vb.'dir. Sistem ile ilişkili faktörler arasında ilaç yükleme etkinliği, fiziksel durum, matriksteki ilaç, partikül büyüklüğü ve dağılımı, gözeneklilik ve iç yapı parçacıkları bulunmaktadır (Jeong vd., 2003). İlaç salım oranını etkileyen faktörler, ilacın bulunduğu matriksin yapısı ve hem polimer hem de ilaçla ilişkili kimyasal özelliklerdir. Salımın kontrol edilebilmesi ilaç iletim sistemlerinin yegâne amacıdır. (Freiberg \& Zhu, 2004). Bu sebeple de kontrollü salım dozaj şekli konunun en önemli kavramıdır. İlaç özelliği, iletim yolu, iletim aracı özelliği, ilaç salım mekanizması, hedefleme yeteneği ve biyouyumluluk ilaç salım dozunu belirler (Park \& Mrsny; 2000). Kontrollü salım terimi, belirtildiği gibi, ilaçların salımını, tekrarlanabilir ve öngörülebilir kinetiklerle uzun süre boyunca nispeten sabit, etkili bir plazma seviyesini koruyacak şekilde kontrol etme tekniğidir. Başarılı bir kontrollü iletim sistemi, yaşlılar ve kronik hastalar dâhil birçok hasta için bir rahatlama olacak olan uygulama sıklığını azaltmalıdır. Ek olarak, ilaç seviyesindeki dalgalanmaları azaltarak yan etkileri en aza indirmek için ilacın sabit-durum seviyesi korunabilir (Langer, 1993).

\subsection{Polimer Esaslı İlaç Taşıyıcı Sistemleri}

Kontrollü salım sistemlerinde en yaygın kullanım ilaçlarda olduğundan kontrollü ilaç salımında kullanılan polimerler genellikle tedavi amaçlı olarak kullanılan polimerler olarak adlandırılırlar. $\mathrm{Bu}$ kullanımlarda ilaçlar polimer matrislerine hapsedilir veya karıştırılır (Vilar vd., 2012; Bayat \& Nasri, 2019). Polimer esaslı ilaç salım sistemlerinin çok çeşitli avantajları bulunmaktadır. Plazmadaki ilaç seviyesini optimal düzeyde tutmak, sistemik ilaçların sebep olduğu yan etkileri azaltmak ve hatta yok etmek, yarılanma ömrü kısa olan ilaçların uygulanmasını kolaylaştırmak, tıbbi gözetime ihtiyaç duyacak 
organlar için ilaç uygulamasını kolaylaştırmak, ucuz ürün ve ilaç atığını azaltmak, ve en önemlisi de hasta memnuniyetinin iyileştirilmesini sağlamak olarak sayılabilir (Paolino vd., 2006; Kost \& Langer, 2012; Bayat \& Nasri, 2019).

\section{2. İlaç Salım Sistemlerinde Polimer Seçimi}

İlaç verimini arttırmak için, beklenen iyileştirici etkiye bağlı olarak ve ilacın fizikokimyasal özellikleri baz alınarak, polimer esaslı formülasyonlar seçilmektedir. Uygun polimer seçimi kritik düzeyde önemlidir, çünkü kullanılan polimer, ilaç enkapsülasyon verimi, ilaç salım oranı, ilacın biyoaktivitesi ve hücre içi etki alanları ile ilaç etkileşimini etkilemektedir. Polimer seçimini etkileyen en önemli faktör ilaç-polimer etkileşimi, polimerin özellikleri (molekül ağırlığı, degrade olabilmesi, yükü, vb.) olduğu kadar ilaç çözünürlügü ve stabilitesi ile salım sisteminin kontrollü mü yoksa hedeflenmiş salım olmasıdır. Burada çeşitli polimerlerle birlikte yardımcı bazı maddelerin de varlığ 1 ve yokluğu da hedeflenen amaca ulaşmada etkili rol oynamaktadır (Raja vd., 2019).

\subsection{Polimer Çeşitleri}

Polimerler; sentetik, doğal ve her ikisinin kombinasyonu şeklinde olabilir. Doğal ve sentetik polimerler de ilaç salım sistemlerinde sıkça kullanılmaktadır.

\subsubsection{Doğal Polimerler}

Doğada bulunan polimerlerdir. Polisakkaridler, proteinler ve polinukleotidler doğal polimerler olarak sınıflandırılmışlardır. Bunlara örnek verilecek olursa, kitin, selüloz, alginat, amiloz, guar gam, ksantan gam, pektin, nişasta, dekstran, siklodekstrin, ipek, elastin, jelatin, kazein, kolajen, hiyaluronik asit, vb.'dir. Doğal polimerler genellikle in vivo koşullarda zararsız olarak nitelendirilmektedir. Farmasötik ve Biyoteknoloji endüstrilerinde yardımcı bileşen, medikal ve dental ekipman olarak kullanılmaktadırlar (Gaspar \& Duncan, 2009). Mükemmel biyouyum ve enzimatik olarak bozunur özellik gösterirler.

$\mathrm{Bu}$ polimerlerin avantajları arasında bol bulunmaları ve kolay saflaştırılabilmelerinin yanı sıra gerekli olan tedaviye yönelik ihtiyaçlar doğrultusunda etki düzeylerinin kimyasal olarak modifiye edilebilmeleri gelmektedir. Fakat doğal polimerlerin bazı sakıncaları da ne yazık ki bulunmaktadır. Bunlar, alınan kaynağa bağlı olan materyal özelliklerinin varyasyonu, mikrobiyel kontaminasyon, kontrol edilemeyen su alımı, zayıf mekanik dayanım, tahmin edilemeyen degradasyon tipidir. $\mathrm{Bu}$ sorunla başa çıkmak için doğal polimerler yarısentetik doğal polimerlere; örneğin, kitin, dekstran, alginat vb. türevleri olarak modifiye edilirler (Raja vd., 2019).

\subsubsection{Sentetik Polimerler}

Polieterler grubuna mensup Polietilen glikol (PEG) veya diğer adıyla polietilenoksit (PEO) ilaç salım sistemlerinde en çok tercih edilen polimerlerdendir (Knop vd., 2010; Liu vd., 2011). PEG nispeten ucuz bir polimer olup, çok çeşitli molekül ağırlıklı ticari formlara sahiptir.

Poliesterler grubu polimerleri de salım sistemlerinde en çok tercih edilen polimerlerden olup, bu gruptaki polimerler ile çok sayıda çalışma literatürde bulunmaktadır. Polilaktid (PLA) biyobozunur alifatik bir poliesterdir. Ortaya çıkan yan ürünler, insan vücudunun zaten ürettiği doğal bir metabolik atık olan laktik asittir. Son derece biyouyumlu ve biyolojik uygulamalar için uygun olmasının sebebi içerdiği laktik asittendir (Alsaheb vd., 2015). PLA olarak kiral bileşenler içerir, bunlar da çeşitli formlarda bulunmaktadır. Bulunan en yaygın formları da Poli(Llaktid) (PLLA), poli(D-laktid) ve poli(D,L,-laktid) (PDLLA)'dir (Tan vd., 2016).

Poliglikolid veya poli(glikolik asit) (PGA) biyomedikal uygulamalarda kullanılan ilk biyobozunur poliester grubu polimerlerdendir (Ulery vd., 2011). Bu alanda en çok kullanılan biyobozunur polimerler poli(laktik asit), poli(glikolik asit) ve kopolimerleri poli(laktik asit-koglikolik asit) (PLGA) gibi poli( $\alpha$-ester)lerdir (Astete \& Sabliov, 2006; Yilgor vd., 2009).

Poli(laktid-ko-glikolit) (PLGA) rastgele polimerizasyon yoluyla PLA (PLLA ve PDLLA ile birlikte) ve PGA'den üretilmiştir (Kaihara vd., 2007). PGA ve PLA'in birbirlerinden farklı özellikleri olmasına rağmen kopolimer bileşeni ile kristalinite ve degrasyon zamanı gibi bazı özelliklerini ayarlama ile son PLGA ürününün eldesi mümkün olabilmektedir (Makadia \& Siegel, 2011). PLGA biyomedikal uygulamalar için araştırmalarda en çok kullanılan poliester grubu polimerdir. Nispeten kısa sürede (birkaç ay) degrade olması sayesinde PLGA'in kullanım sıklığını arttırmaktadır. Örnek olarak, kanser tedavileri (Mirakabad vd., 2014; Roullin vd., 2002; Mu \& Feng, 2003), antienflamatuar ilaçlar (Hermans vd., 2014; Parra vd., 2015), proteinler (Feczko' vd., 2011; Allahyari \& Mohit, 2016), ve siRNA (Pantazis vd., 2012; Cun vd., 2011) verilebilir.

Polikaprolakton (PCL), $\varepsilon$-kaprolakton monomerinden halka açılma polimerizasyonu vasıtasıyla sentezlenen bir poliester polimeridir (Oshimura ve diğ., 2009). Yar1-kristal polimer olup erime sıcaklığ $\mathrm{Tm}=60^{\circ} \mathrm{C}$, camsı geçiş sıcaklığ $1 \mathrm{Tg}=-60^{\circ} \mathrm{C}$ civarındadır. Kristallik özellik, PCL'a yüksek hidrofobisite vermekte, bu sayede degradasyon oranını yavaşlamaktadır (Lam vd., 2007). Degradasyon prosesi molekül ağırlığına bağlı olarak 3 yıl civarında gerçekleşir (Woodruff \& Hutmacher, 2010). PCL'un abiyotik hidrolize karşı nispeten stabil olmakla birlikte, biyotik bozulmaya duyarlı olduğu gösterilmiştir (Fukushima vd., 2013).

\subsection{Aktif Bileşenlerin Kontrollü Salımı için Polimerik Mikro- ve Nanoparçacıklar}

Mikroparçacıklar ve nanoparçacıklar, ilaç dağıtımı, görüntüleme ve temel araştırma dâhil olmak üzere çok çeşitli biyomedikal uygulamalar üzerinde büyük bir etkiye sahiptir. Mikroparçacıklar ve nanoparçacıklar üzerine geniş bir veri tabanı olmasına rağmen, literatürde nano ve mikroboyut arasında açık bir evrensel sınır yoktur. Ancak yine de, mikron (1-1000 $\mu \mathrm{m})$, alt mikron $(100-1000 \mathrm{~nm})$ ve nanometre $(1-100 \mathrm{~nm})$ ölçekleri olarak belirlendiğini söylemek yanlış olmaz. (George vd., 2005).

Mikro ve nano bilimlerdeki uzman görüşleri, 1-100 nm'nin optimum nano ölçekli aralık olduğunu vurgulamıştır; ancak, biyoteknoloji ve tıpta, "nano" tanımı daha az katıdır (Ferrari, 2005). Herhangi bir minyatür sistemin tasarımı uç nokta uygulamasına bağlıdır. Örneğin, sistemik (damar içi) uygulama, çap1 500 nm'den küçük parçacıkların kullanılmasını gerektirirken, kas içi uygulama veya bazı durumlarda oral uygulamalarda 1 mikrondan büyük ve $125 \mu$ m'den küçük parçacıklar kolayca uygulanabilir (Jain, 2000). Boyuttan başka, bu parçacıkların işlevini önemli ölçüde modüle edebilen bir başka kritik parametre şekil olup; şekil, bağışıklık hücreleri tarafından hücre alımını, biyomoleküllerin salım davranışını ve hücre hedeflemesini etkileyebilir (Champion vd., 2007). Çoğunlukla hormonlar, aşı antijenleri ve adjuvanlar, peptitler ve 
anti-enflamatuar ajanlar gibi terapötik biyomoleküllerin görüntülenmesi veya hedefli verilmesi için çeşitli materyaller mikro ve nanopartiküller olarak sentezlenmiştir (Aukunuru vd., 2003; Kim vd., 2004). Ek olarak, bu parçacıklar biyosensör olarak ve afinite biyo-ayrıştırmalarında, immünolojik analizlerde, hücre etiketlemesinde ve hücre sinıflandırmasında kullanılmıştır.

Poliester mikro ve nanoparçacıklar çeşitli sınıflardan ilaçların kontrollü salımı için kullanılmaktadır. Bu ilaçlara örnek olarak antikanser ajanları, büyüme faktörleri, antibiyotikler, antimikrobiyal ajanlar vb. verilebilir. Mikroküre olarak adlandırılan sistemin polimer ve aktif ajanlarının oldukça homojen karışması yaygın olarak kabul görmekte olup, mikropartiküllerin en az bir ve birden çok ayrık aktif ajan alanı bulunmaktadır (Stevanović, 2017).

\section{Enkapsülasyon}

Kapsülleme, bir maddeyi diğerinin içinde tutabilecek birkaç $\mathrm{nm}$ ile birkaç mm çapa sahip parçacıklar üretilebilen bir proses olarak tanımlanabilir. Kapsüllenen maddeye çekirdek malzeme, aktif madde, dolgu veya iç faz; kapsülleyen maddeye ise kaplama, membran, kabuk, taşıyıcı malzeme, duvar malzemesi, dış faz veya matriks denilebilir. Bu teknikte temel amaç; ilaçlar, gıda maddeleri, aroma maddeleri gibi pek çok aktif bileşenin stabil kalmak suretiyle salımını kontrollü olarak gerçekleştirmektir (Açu vd., 2014).

İki ana kapsülleme tipi vardır. Bunlar rezervuar tipi ve matriks tipidir. Küresel enkapsülantların yanı sıra silindirik, oval ya da düzensiz şekilli enkapsülantlar bulunabilmektedir. Rezervuar tipi enkapsülant aktif ajanın etrafinda bir kabuğa sahiptir. Ayrıca bu tip; kapsül, tek çekirdekli veya çekirdekli kabuk tipi olarak da adlandırılır. Bir parçacıkta birkaç tane haznesi olan çoklu çekirdek tipi kapsüller de bulunmaktadır. Matriks tipindeki aktif madde, taşıyıcı malzeme üzerinde çok daha fazla dağılır. Böylece küçük damlacıklar halinde ya da enkapsülant üzerine homojen bir şekilde dağılmış şekilde olabilmektedir. Matriks tipi enkapsülanttaki aktif maddeler rezervuar tipindekilerin aksine genel olarak yüzeyde bulunur (Zuidam \& Nedovic, 2010).

Enkapsülasyon önemli ve özellikli bir proses olduğundan ideal bir kaplama materyalinin seçimi de önem arz etmektedir. $\mathrm{Bu}$ sebeple enkapsülasyonda kullanılacak kaplama materyalinin reolojik özellikleri çok iyi olmalı ve kolay işlenebilmelidir. Emülsiyon ve dispersiyon özellikleri iyi olmalı, emülsiyon stabilitesinin ise yüksek olması gerekmektedir. Kaplama materyali ile çekirdek materyal hiçbir şekilde reaksiyona girmemelidir. İstenilen çözücüde çözünebilen, maliyeti düşük, sadece çekirdek materyali kaplamamalı, aynı zamanda depolama sırasında da çekirdek materyali koruyabilir olmalıdır (Koç vd., 2010).

Aktif bileşenlerin polimer taşıyıcıların içine hapsedilmesi yani enkapsülasyonu için farklı yöntemler kullanılmaktadır. $\mathrm{Bu}$ yöntemlerin en önemlileri; termal faz ayrımı, eriyik dispersiyonu, solvent buharlaştırma, sprey kurutmadır. Su ve organik fazların homojenizasyonu da kullanılan diğer teknikler arasında bulunmaktadır (Stevanović, 2017).

Seçilen materyale bağlı olacak şekilde, aktif bileşenlerin salımında kullanılacak polimerik parçacıkların yapımında kullanılan teknikler çeşitli gruplar halinde incelenebilir. Örneğin, literatürde, polyester polimer PLGA'den parçacıkların e-ISSN: 2148-2683 yapılabilmesi için birçok yaklaşım önerilmektedir. Emülsifikasyon-buharlaşma metodu (Astete vd., 2007; Prabha \& Labhasetwar, 2004; Sahoo \& Labhasetwar, 2005; Song vd., 2006), emülsifikasyon-çözücü difuzyon methodu (Lee vd., 2005; Zhang vd., 2006), nanopresipitasyon (Bilati vd., 2005; Govender vd., 1999), ve sprey-kurutma (Atuah vd., 2003; Rivera vd., 2004; Takashima vd., 2007) yöntemleri yaygın olarak çeşitli boyutlarda PLGA mikro- ve nanoparçacıkların yapımında kullanılmaktadır. $\mathrm{Bu}$ yöntemler, bir su / yağ dispersiyonu oluşturmak için organik bir çözelti içinde sulu bir ilaç çözeltisinin emülsifiye edildiği karşılaştırılabilir birincil aşamalara sahiptir. İlaç ayrıca organik polimerik çözelti içinde bir toz (katı parçacıklar) halinde dağıtılabilir veya bir çözücü içinde polimer ile birlikte çözülebilir. Daha sonra çözelti veya dispersiyon, yukarıda belirtilen tekniklerden birine göre işleme tabi tutulur.

Çözücü (solvent) ekstraksiyon veya buharlaştırma prosedürü kullanıldığında, polimer, bir organik çözücü; örneğin, diklorometan, aseton, asetonitril, kloroform veya etil asetat içinde çözdürülür. Bu çözücüler, aynı zamanda hidrofobik ilaçlar için de çözücü olarak kullanılırlar. Polimer ve ilaç karışımı, suda çözünen yüzey aktif madde (sürfaktan), stabilizatör, veya emülsifiye edici ajan ile emülsifiye edilmek suretiyle su içinde yağ emülsiyonu yapılırlar. Stabil emülsiyon oluştuğunda, organik çözücü, ya basınç düşürülerek ya da sürekli karıştırılarak buharlaştırılır. Parçacık boyutu ve morfoloji üzerinde farklı parametrelerin etkisi bulunmaktadır. Bunlara örnek; stabilizatörün çeşidi ve konsantrasyonu, homojenizasyon hızı ve polimer konsantrasyonudur (Kwon vd., 2001).

Solvent-difüzyon tekniği solvent-buharlaştırma prosesinin uyarlanmış versiyonudur. $\mathrm{Bu}$ prosedürde, su ile karışabilen çözücü (solvent) ile birlikte su ile karışamayan organik çözücü beraber kullanılarak yağ fazı oluştururlar. Çözücülerin spontane difüzyonu sayesinde, iki faz arasında küçük parçacıkların oluşumunu tetikleyen ara yüzey türbülansı artar. Çözücü buharlaşması yanı sıra çözücü difüzyonu, yöntemler hidrofobik veya hidrofilik ilaçlar için kullanılabilir. Hidrofilik ilaçlar olduğu durumda, iç sulu fazda ilacın çözünmesine ihtiyaç duyulduğundan çoklu su/yağ/su emülsiyonu ihtiyacı ortaya çıkar.

Koaservasyon metodu sürekli çalkalama altında 3 kısımdan oluşan bir tekniktir. Birinci kısımda, çözelti üç birbirine karışmayan fazdan oluşmalıdır. Çekirdek malzeme (aktif bileşen), kaplama malzemesi (polimerik malzeme) ve çözücü; sıvı kaplamanın çekirdek materyalin etrafına yerleştirildiği ikinci kısım; bu, kaplama fazının çözücü fazı (aktif maddelerin içinde bulunduğu) ile karıştırılmasıyla elde edilir; ve üçüncü kısım ise, kaplama termal olarak veya desolvasyon ile sertleştirildiğinde elde edilir (Thomasin vd., 1998a,b).

\section{Enkapsülasyon Teknikleri}

Eczacılık, tıp ve gıda endüstrilerinde farklı enkapsülasyon ve immobilizasyon teknikleri yaygın olarak kullanılmaktadır (Kumar, 2000; Stupar vd., 2014; Wieland-Berghausen vd., 2002). Enkapsülasyon, çevreye duyarlı bileşenleri korur veya aktif maddelerin zamanla salınmasını sağlar. Bazı bileşenlerin geleneksel teknikler kullanılarak enkapsüle edilmesi kolaydır. C vitamini gibi hassas suda çözünür bileşenlerin enkapsülasyonu çok zordur, bu nedenle kontrollü koruma ve ona bağlı olarak da kontrollü salım gereklidir (Stevanović, 2017). 
Mikro veya nanopartiküller içindeki vitaminler, mineraller veya diğer besinler gibi aktif maddelerin enkapsülasyonu için yaygin olarak kullanılan teknikler termal faz ayırma (koaservasyon), sprey soğutma ve dondurma, eriyik dağılımı, çözücü buharlaşması, akışkan yatak kaplaması, sprey kurutma, su ve organik fazların homojenizasyonu, dönel süspansiyon ayırma, ekstrüzyon ve inklüzyon kompleksi, vb.'dir (Stevanović, 2017).

\subsection{Termal Faz Ayırma (Koaservasyon)}

Koaservasyon (termal faz ayrımı) kullanılarak, aktif madde mikrokapsül oluşumuna yol açan bir polimer kabuğu ile kaplanır (Wieland-Berghausen vd., 2002). Etil selüloz, koaservasyon işleminde en yaygın olarak kullanılan polimerdir (Benita \& Donbrow, 1982; Miller \& Anderson, 1964; Uddin vd., 2001; Yalabik-Kas, 1983; Yoshiyuki vd., 1983). Homojenizasyon hızı, soğutma hızı, faz ayrımı indükleme maddesinin konsantrasyonu ve etil selülozun viskozitesi / moleküler ağırlığ gibi çeşitli faktörler kapsülleme etkinliği ve kapsüllenmiş ilacın salım davranışı üzerinde bir etki gösterir. Uddin vd. (2001) bu tekniği kullanarak vitaminleri enkapsüle etmiştir. Duvar oluşturan malzeme olarak etil selüloz kullanılmıştır. Etil selülozun molekül ağırlığı değiştirilmiş ve etil selülozun molekül ağırlığının ve poliizobütilen ilave edilmesinin askorbik asit içeren mikrokapsüllerin birikmesini ve salım hızını önemli ölçüde etkilediği belirlenmiştir. Etil selülozun molekül ağırlığı arttıkça mikroenkapsülasyon ürününün boyutunun azaldığı tespit edilmiştir (Stevanović, 2017).

\subsection{Eriyik Dispersiyon}

Eriyik dispersiyon tekniğinde, ilaç içeren erimiş mum fazı, 1sıtılmış, emülgatör içeren bir dış faza emülsifiye edilir. İlacın çözünürlüğüne bağlı olarak, harici faz sulu (suda çözünmeyen ilaçlar için) veya susuz (suda çözünür ilaçlar için) olabilir. Emülsiyonun soğutulması üzerine, sıvı damlacıkları katılaşır ve balmumu mikropartiküllerinin bir süspansiyonu oluşur. Mikropartiküller daha sonra çoğunlukla filtrasyon veya santrifüj ile ayrılır, bazen serbest ilaç kristallerini ve yüzey aktif cisimlerini çıkarmak için yıkanır, kurutulur ve boyutlandırılır. Askorbik asidin enkapsüle edilmesinde eriyik dispersiyon yönteminde karnauba mumu kullanılmıştır (Uddin vd., 2001). Yapılan başka bir çalışmada ise, "sıcakta eriyen" mikroenkapsülasyon; kapsüllenmiş boyalar (asit-turuncu), pnitroanilin veya insülin ile polianhidrit mikrokürelerin elde edilmesi için bir yöntem olarak tarif edilmiştir (Mathiowitz ve Langer 1987).

\subsection{Sprey Kuutma}

Spreyle kurutma, bir çözeltiden veya süspansiyondan katı formülasyonlar üreten ve ilaç ve gıda endüstrisinde özel uygulamalara sahip iyi bilinen bir tekniktir (Stevanović, 2017). Spreyle kurutma, daha sonra sicak hava veya azot içeren bir kurutma odasına enjekte edilen sivı beslemenin atomizasyonunu içeren tek aşamalı bir işlemdir. Damlacıklar anında kurutma bölmesinde toplanan katı partiküller halinde kurutulur. Çıktı malzemesinin özelliklerini etkileyebilecek iki faktör, püskürtülerek kurutulmuş parçacık formülasyon faktörleri ve püskürtmeyle kurutma parametreleridir (Seville, 2007). C vitamini için bir hazırlama yöntemi olarak sprey kurutma kullanılan çalışmalar literatürde mevcuttur (Esposito vd., 2002; Finotelli ve Rocha-Leao, 2005).

\subsection{Sprey Dondurma ve Sprey Soğutma}

e-ISSN: 2148-2683
Sprey dondurma ve sprey soğutma, çekirdek malzemenin sıvılaştırılmış bir kaplama veya duvar malzemesi içinde dağıldığı ve atomize edildiği, ancak genellikle buharlaştırılacak su olmadığı için sprey kurutmaya benzer yöntemlerdir. Çekirdek ve duvar karışımı, duvarın çekirdeğin etrafında katılaşmasına neden olan soğuk havaya atomize edilir (Risch \& Reineccius, 1995). Sprey dondurmada, kaplama tipik olarak fraksiyone veya hidrojene bir yağdır. Sprey soğutmasında, duvar tipik olarak yağdır, ancak başka malzemeler de kullanılabilir. Bu yöntemler aslında sadece kullanılan duvar malzemesinin erime noktasında farklılık gösterir ve çoğunlukla vitaminler, mineraller veya asitleştiriciler gibi katı malzemeleri kapsüllemek için kullanılır (Stevanović, 2017).

\section{5. Çözücü Buharlaştırma Tekniği}

Kontrollü salımı yapılan ilaçları elde edebilmek için ilaç endüstrisinde yaygın olarak kullanılan bir mikroenkapsülasyon tekniğidir. İçinde hapsolmuş ilaca sahip olan elde edilen polimer mikrokürecikler, enkapsüle edilmiş ilacı, spesifik bir salma profiliyle yavaşça bozabilir ve salıverebilir. (Berkland vd., 2002; Freiberg \& Zhu, 2004). Bu metodda polimer ile ilaç uçucu solvent ile karıştırılmak suretiyle emülsiyon oluşturulur. Buharlaştırma aşamasına gelindiğinde, solvent emülsiyonu süspansiyona dönüştürmüş olur. Bundan sonra katı parçacıklar santrifüj/ultrasantrifüj yoluyla safsızlık ve katkı maddelerinden ayrılırlar. Sonraki aşamada kurutma ile katı parçacıklar elde edilir. Kurutma işleminde, en çok da kullanılan ilaca bağlı olarak, liyofilizasyon yöntemi tercih edilebilir. Sprey kurutucuda, vakum ortamında vb. şekilde kurutarak katı parçacıkları elde etmek mümkündür (Nagavarma vd., 2012).

Emülsifikasyon-buharlaştırma yöntemi (Astete vd., 2007; Prabha \& Labhasetwar, 2004; Sahoo \& Labhasetwar, 2005; Song vd., 2006), spontane emülsifikasyon-çz̈zücü difüzyon yöntemi (Lee vd., 2005; Zhang vd., 2006), nanopresipitasyon yöntemi (Bilati vd., 2005; Govender vd., 1999), çözücü buharlaştırma ve sprey kurutma yöntemi (Atuah vd., 2003; Rivera vd., 2004; Takashima vd., 2007) çeşitli boyutlarda mikro ve nanoparçacıklar hazırlamak için yaygın olarak kullanıılır. Bu yöntemlerin her biri benzer bir ilk adımı kullanır, burada sulu bir ilaç çözeltisi, bir yağ içinde su dispersiyonu (w/o) oluş̧urmak için bir organik polimer çözeltisi içinde emülsifiye edilir (O’Donnell \& McGinity, 1997). Uygun olduğu takdirde, bileşen ayrıca bir organik polimer çözeltisi içinde bir katı madde olarak dağıtılabilir veya polimer ile birlikte ortak bir çözücü içinde çözülebilir. Çözücü buharlaştırma tekniğinde, ilaç maddesi polimer içinde homojen olarak dağıtılır. Partikül boyutu, stabilizör tipi ve konsantrasyonu, homojenizasyon hızı ve polimer konsantrasyonundan etkilenir (Kwon vd., 2001). Bununla birlikte, bu teknik suda çözünür ilaçlar için düşük enkapsülasyon verimine yol açar (Bodmeier vd., 1994; WielandBerghausen vd., 2002).

Enkapsülasyon tekniğinin etkinliğini artıran yöntem seçiminde ilacın hidrofilik veya hidrofobik olması etkin rol oynar. Sulu çözeltide kısmen çözünen ya da çözünmeyen ilaçlar için suda yağ $(\mathrm{o} / \mathrm{w})$ emülsiyonu sıklıkla kullanılmaktadır. $\mathrm{Bu}$ yöntem en basit olanıdır ve bu özelliği ile diğerlerinden ayrılır. Dört ana basamak içerir: (I) Polimer içeren bir organik çözücüde hidrofobik ilacın çözünmesi; (II) Sürekli faz olarak adlandırılan sulu fazda, dispers (dağılmış) faz olarak adlandırılan bu organik fazın emülsifikasyonu; (III) Çözücünün dispers (dağılmış) fazdan sürekli faz ile ekstrakte edilmesi, çözücünün buharlaştırılması ile birlikte dağılmış fazın damlacıklarının katı 
parçacıklara dönüştürülmesi; (IV) Kalıntı çözücüyü ortadan kaldırmak suretiyle mikrokürelerin geri kazanılması ve kurutulması (Li vd., 2008).

Bahse konu yöntem aşırı hidrofilik ilaçların enkapsülasyonu için uygun değildir. Bunun iki ana sebebi bulunmaktadır. Birinci sebep; hidrofilik ilaç organik çözücüde çözünmez. İkinci sebep ise ilaç emülsiyon sırasında sürekli faza dağılır ve bu da büyük ilaç kayıplarına neden olur. Hidrofilik ilaçları enkapsüle etmek için dört farklı alternatif yöntem önerilmektedir (Li vd., 2008):

1- w/o/w-çift emülsiyon yöntemi: Hidrofilik ilacın sulu çözeltisi organik faz ile emülsifiye edilir (w/o emülsiyonu), bu emülsiyon daha sonra ikinci bir emülsiyon oluşturan ikinci bir sulu çözeltiye dağıtılır (w/o/w);

2- o/w-yardımcı çözücü yöntemi: Ana organik çözücüde ilaç çözünmediği zaman ilacı dağıtmak için yardımcı çözücü olarak adlandırılan ikinci bir çözücü gerekmektedir.

3- o/w-dağılma yöntemi: İlaç, polimer ve organik çözücü çözeltisinde katı toz halinde dağılır.

4- o/o-susuz çözücü buharlaştırma yöntemi: Sulu faz yağ ile (örn: mineral yağ) yer değiştirilir.

Aynı ilaç için ilaç enkapsülasyon etkinliği, kullanılan yönteme göre değişebilmektedir (Herrmann \& Bodmeier, 1998). Elde edilen mikrokürelerin fiziksel özellikleri, malzemelerin doğasına ve ayrıca mikrokürelerin imalatı sırasındaki parametrelere bağlıdır (Izumikawa vd., 1991; O'Donnell \& McGinity, 1997; André-Abrant vd., 2001).

Emülsifikasyon, emülsifikasyon çözücü buharlaşma yönteminin ana ve ilk adımıdır (Rosca vd., 2004). Bununla birlikte, emülsiyon damlacıklarından çözücü taşınması olan ikinci adım, parçacıkların morfolojisi ve mikropartiküllerin enkapsülasyonu ve salım davranışı üzerinde büyük etkiye sahiptir. Rosca vd. (2004), emülsiyon damlacıklarından çözücü eliminasyon mekanizmasını ve parçacık morfolojisi, kapsülleme ve salım davranışı üzerindeki etkisini incelemiştir. Çözücü oldukça uçucu olduğundan, çözücü uzaklaştırmayı gözlemlemek, bu aşama hızlı olduğundan zordur (Stevanović, 2017). Bu aşamada bazı durumlar ortaya çıkmaktadır. Çözücünün yoğun buharlaştırılması sırasında, enkapsüle edilmiş ilacın kendiliğinden ortama boşalması görülür. Mikropartikül yüzeyinin yakınında yoğunlaşan ilacın ani salımı patlama (initial burst release) şeklinde ortaya çıkar. Bundan dolayı bu durum da ilaç yükleme verimini etkilemektedir.

Çözücü buharlaştırma yöntemiyle mikroenkapsülasyonda uygun bir çözücü seçebilmek de önemlidir. Bunun için dikkat edilmesi gerekenler ise; seçilen polimeri çözebilir olması, sürekli fazda oldukça az çözünür olmak, yüksek uçuculuğa ve düşük kaynama noktasına sahip olmak, düşük toksisiteye sahip olmaktır (Li vd., 2008). Kloroform eskiden daha sıklıkla kullanılırdı. Ancak toksisitesi ve düşük buhar basıncı nedeniyle son zamanlarda metilen klorür daha sık kullanılmaktadır. Metilen klorür; yüksek uçuculuğu, düşük kaynama noktası ve suyla karışmazlığı nedeniyle çözücü buharlaştırma tekniği kullanılarak enkapsülasyon için en yaygın olarak kullanılan çözücüdür. Diğer çözücülere kıyasla yüksek doymuş buhar basıncı (en az iki kat daha yüksek), mikrokürelerin oluşum süresini kısaltan yüksek bir buharlaşma hızı sunmaktadır. Bununla birlikte, bu çözücünün EPA (Çevre Koruma Ajansı) verilerine göre kanserojen olduğu onaylanmıştır ve araştırmacılar daha az toksik çözücü bulmak için büyük çaba sarf etmektedir (Li vd., 2008). Etil asetat, metilen klorüre göre daha az toksiktir. $\mathrm{Bu}$ nedenle umut verici bir potansiyel göstermektedir. Ancak etil asetatın suya kısmi olarak karışması nedeniyle (metilen klorürün 4.5 katı kadar), organik faz (dağılan faz) doğrudan sürekli faza dâhil edilirse, mikroküreler oluşamamaktadır. Organik fazdan büyük miktarda etil asetatın aniden çıkarılması, polimerin lif benzeri topaklara dönüşüp çökmesine neden olur (Freytag vd., 2000; Li vd., 2008). Çözücülerin suyla karışmasının yarattığı bu sorunu çözmek için kullanılan yöntemler vardır. Bu yöntemlerde, sulu çözelti çözücü ile önceden doyurulur (Bahl \& Sah, 2000), organik faz önce az miktarda sulu çözelti içerisinde emülsiyon haline getirilir; damlaların oluşumundan sonra bu emülsiyon büyük miktarda sulu çözeltiye dökülür (Freytag vd., 2000) veya organik faz az miktarda sulu çözeltide emülsifiye edilir, çözelti yüksek hızla çalkalanır ve çözücü buharlaşarak mikrokürelerin katılaşmasına neden olur (Sah, 1997).

Yukarıdaki metotlarla etil asetat kullanılarak mikroküreler başarıyla elde edilir. Bununla birlikte, metilen klorür tarafından hazırlanan mikroküreler daha küresel ve homojendir, ancak etil asetat kullanımı kısmen parçalanmış gibi görünen parçacıklar oluşturur (Herrmann \& Bodmeier, 1998). İlaç kapsülleme etkinliği, Herrmann \& Bodmeier'e (1998) göre metilen klorür tarafindan yapılan mikrokürelere karşı önemli ölçüde azalır. Bu durumun su içinde etil asetatın yüksek çözünürlüğüne bağlı olduğunu ve sonuç olarak ilaç kaybına yol açtığını varsaymıştır.

Özetle; daha az toksik çözücüler test edilmekte ve gelecek vaat etmektedir. Ancak farklı çözücüler kullanılarak hazırlanan mikrokürelerin kalitesini karşılaştırabilecek yeterli sonuçlar bulunmamaktadır. Metilen klorür; hızlı buharlaşması, yüksek ilaç kapsülleme verimi, küresel ve daha tekdüze bir formda mikroküreler elde edilebilmesi gibi sebeplerle hala en çok kullanılan çözücü durumundadır.

Emülsiyonlar için yüzey aktif maddeler amfifiliktir. Bunun anlamı; bu molekülün bir kısmının, su (hidrofilik) gibi polar çözünenlere daha fazla çekim gücüne sahip olduğu ve diğer kısmının, hidrokarbonlar (hidrofobik) gibi polar olmayan çözünenlere daha fazla çekim gücüne sahip olduğu anlamına gelir. Bir emülsiyon içinde olduğunda yüzey aktif madde; damladaki hidrofobik kısmı ve sudaki hidrofilik kısmı ile damla yüzeyini kaplar. Yüzey aktif maddenin tipini ve konsantrasyonunu seçmeden önce, iki karışmayan fazın polaritesini, istenen mikroküre büyüklüğünü ve küresellik isteğini tam olarak bilmek önemlidir. Tensioaktif madde olarak da adlandırabildiğimiz yüzey aktif madde, bir fazın başka bir karışmayan fazda dispersiyonu ve elde edilen emülsiyonun stabilizasyonu için sıklıkla kullanılmaktadır. Sürekli fazın yüzey gerilimini azaltarak damlaların birikmesini ve birleşmesini engeller böylelikle emülsiyonu stabilize eder. Uygun bir yüzey aktif madde, düzenli/tekdüze ve küçük boyutta mikroküre dağılımı verebilmelidir. Böylece daha öngörülebilir ve kararlı bir ilaç salımı garanti edilebilir (Li vd., 2008). Molekülün hidrofilik kısmının doğası ile sınıflandırılmış dört farklı yüzey aktif madde tipi vardır. Bunlar; anyonik, katyonik, amfoterik ve iyonik olmayan yüzey aktif madde olarak isimlendirilmektedir. Yüzey aktif maddeler arasında özellikle hidrolize PVA (Polivinil alkol) en sık kullanılanıdır. Çünkü bu yüzey aktif madde ile en küçük mikroküreler elde edilebilmektedir (Li vd., 2008). PVA dışında başka yüzey aktif maddeler de kullanılmaktadır. Bunlar da ilacın özellikleri ve enkapsülasyon yöntemine bağlı olarak değişiklik göstermektedir. 


\section{Sonuç}

$\mathrm{Bu}$ derlemede aktif bileşenlerin özellikle de ilaçların uygun biyobozunur ve biyouyumlu polimerlerle ve en yaygın kullanılan yöntemlerle nasıl enkapsüle edilebileceği kısaca ele alınmıştır. Hâlihazırda, kontrollü ve dengeli aktif madde salımına sahip bir sistem ihtiyacına dayalı olarak, tıp, eczacılık ve gıda endüstrisi alanlarında polimer taşıyıcı sistemlere büyük ilgi duyulmaktadır. $\mathrm{Bu}$ amaçla mikro ve nanoparçacık araştırmalarında farklı yöntemlerin uygulamalarının yakın gelecekte yaygınlaşacağ öngörülmektedir.

\section{Kaynakça}

Açu, M., Kınık, Ö., \& Yerlikaya, O., 2014, Mikroenkapsülasyon ve Süt Teknolojisindeki Yeri, Akademik Gıda, 12(1), 97107.

Allahyari, M. \& Mohit E., 2016, Peptide/protein vaccine delivery system based on PLGA particles, Hum Vaccines Immunother, 12(3), 806-828.

Alsaheb, R.A.A, Aladdin, A., Othman, NZ., Malek, R.A., Leng, O.M., Aziz, R.\& Enshasy, H., 2015, Recent applications of polylactic acid in pharmaceutical and medical industries, J Chem Pharm Res., 7, 51-63.

André-Abrant, A., Taverdet, J.-L. \& Jay, J., 2001, Microencapsulation par évaporation de solvant, Eur. Polym. J, 37, 955-967.

Astete, C.E., Kumar, C.S.S.R. \& Sabliov, C.M., 2007, Size control of poly(d,1-lactide-co-glycolide) and poly(d,1-lactideco-glycolide)-magnetite nanoparticles synthesized by emulsion evaporation technique, Colloids Surf. A, 299, 209216.

Astete, C.E., \& Sabliov, C.M., 2006, Synthesis and Characterization of PLGA Nanoparticles. J. Biomaterials Sci Polymer Ed., 17, 247-289.

Atuah, K.N., Walter, E., Merkle, H.P. \& Alpar, H.O., 2003, Encapsulation of plasmid DNA in PLGA-stearylamine microspheres: a comparison of solvent evaporation and spray-drying methods, J. Microencapsul, 20 (3), 387-399.

Aukunuru, J.V., Ayalasomayajula, S.P. \& Kompella, U.B., 2003, Nanoparticle formulation enhances the delivery and activity of a vascular endothelial growth factor antisense oligonucleotide in human retinal pigment epithelial cells, Journal of Pharmacy and Pharmacology, 55(9), 1199-1206.

Bahl, Y. \& Sah, H., 2000, Dynamic changes in size distribution of emulsion droplets during ethyl acetate-based microencapsulation process, AAPS PharmSciTech., 1, 4149.

Bayat, M. \& Nasri, S., 2019, Injectable microgel-hydrogel composites "plum pudding gels": new system for prolonged drug delivery, Nanomaterials for Drug Delivery and Therapy, In: Grumezescu, A.M.(ed.), Bölüm 12, Elsevier, New York, ISBN: 978-0-12-816505-8, 343-372.

Berkland, C., King, M., Cox, A., Kim, K.K. \& Pack, D.W., 2002, Precise control of PLG microsphere size provides enhanced control of drug release rate, Journal of Controlled Release, 82(1), 137-147.

Besenbache, F., Sutherland, D.S. \& Hovgaard, M.B., 2007, From nanoscience to nanotechnology: utilizing the nanoscale, Toxicol. Lett., 172 (1), S34.

Bilati, U., Allémann, E. \& Doelker, E., 2005, Development of a nanoprecipitation method intended for the entrapment of hydrophilic drugs into nanoparticles, Eur. J. Pharmacol., 24, $67-75$.

Bodmeier, R., Wang, H. \& Hermann, J., 1994, Microencapsulation of chlorpheniraminemaleate, a drug with intermediate solubility properties, by a non-aqueous solvent evaporation technique, STP Pharma. Sci., 4 (4), 275-281.

Champion, J.A., Katare, Y.K. \& Mitragotri, S., 2007, Making polymeric micro- and nanoparticles of complex shapes, Proc. Natl. Acad. Sci. USA, 104(29), 11901-11904.

Cun, D., Jensen, D.K., Maltesen, M.J., Bunker, M., Whiteside, P., Scurr, D., Foged, C. \& Nielsen, H.M., 2011, High loading efficiency and sustained release of siRNA encapsulated in PLGA nanoparticles: quality by design optimization and characterization, Eur J Pharm Biopharm, 77(1), 26-35.

Feczko', T., To'th, J., Do'sa, G. \& Gyenis, J., 2011, Optimization of protein encapsulation in PLGA nanoparticles, Chem Eng Process, 50(8),757-765.

Feng, S.S., Mu, L., Yin Win, K. \& Huang, G., 2004, Nanoparticles of biodegradable polymers for clinical administration of paclitaxel, Curr. Med. Chem., 11, 413424.

Ferrari, M., 2005, Cancer nanotechnology: Opportunities and challenges, Nature Reviews Cancer, 5(3), 161-171.

Finotelli, P.V. \& Rocha-Leao, M.H.M., 2005, Microencapsulation of ascorbic acid in maltodextrin and capsul using spray-drying, 2nd Mercosur Congress on Chemical Engineering and 4th Mercosur Congress on Process Systems Engineering, 14-18 Ağustos 2005, Rio de Janeiro, Brezilya, 1-11.

Freiberg, S \& Zhu, X.X., 2004, Polymer microspheres for controlled drug release, International Journal of Pharmaceutics, 282, 1-18.

Freytag, T., Dashevsky, A., Tillman, L., Hardee, G.E. \& Bodmeier, R., 2000, Improvement of the encapsulation efficiency of oligonuclleotide-containing biodegradable microspheres, J. Contr. Rel, 69, 197-207.

Fukushima, K., Feijoo, J.L. \& Yang, M-C., 2013, Comparison of abiotic and biotic degradation of PDLLA, PCL and partially miscible PDLLA/PCL blend, Eur Polym J, 49(3), 706-717.

Gaspar, R. \& Duncan, R., 2009, Polymeric carriers: preclinical safety and the regulatory implications for design and development of polymer therapeutics, Adv Drug Deliv Rev ., 61(13), 1220-1231.

George, P.M., Lyckman, A.W., LaVan, D.A., Hegde, A., Leung, Y., vd., 2005, Fabrication and biocompatibility of polypyr $\neg$ role implants suitable for neural prosthetics, Biomaterials, 26(17), 3511-3519.

Govender, T., Stolnik, S., Garnett, M.C., Illum, L. \& Davis, S.S., 1999, PLGA nanoparticles prepared by nanoprecipitation: drug loading and release studies of a water-soluble drug, J. Control. Rel., 57, 171-185.

Hermans, K., Van den Plas, D., Schreurs, E., Weyenberg, W. \& Ludwig, A., 2014, Cytotoxicity and anti-inflammatory activity of cyclosporine A loaded PLGA nanoparticles for ocular use, Die Pharm, 69(1), 32-37.

Herrmann, J., \& Bodmeier, R., 1998, Biodegradable somatostatin acetate containing microspheres prepared by various aqueous and non-aqueous solvent evaporation methods, Eur. J. Pharm. Biophar,. 45, 75-82.

Izumikawa, S., Yoshioka, S., Aso, Y., \& Takeda, Y., 1991, Preparation of poly(l-lactide) microspheres of different 
crystalline morphology and effect of crystalline morphology on drug release rate, J. Contr. Rel. 15, 133-140.

Jain, R.A., 2000, The manufacturing techniques of various drug loaded biodegradable poly(lactide-co-glycolide) (PLGA) devices, Biomaterials, 21(23), 2475-2490.

Jeong, J.C., Jaeyoung, L. \& Cho, K., 2003, Effects of crystalline microstructure on drug release behavior of $\operatorname{poly}(\varepsilon-$ caprolactone) microspheres, Journal of Controlled Release, 92, 249-258.

Kaihara, S., Matsumura, S., Mikos, A.G., \& Fisher, J.P., 2007, Synthesis of poly(L-lactide) and polyglycolide by ringopening polymerization, Nat Protoc.,2(11), 2767-2771.

Kim, S., Lim, Y. T., Soltesz, E. G., De Grand, A. M., Lee, J., et al., 2004, Near-infrared fluorescent type II quantum dots for sentinel lymph node mapping. Nat. Biotechnol., 22(1), 9397.

Knop, K., Hoogenboom, R., Fischer, D., \& Schubert, U.S., 2010, Poly(ethylene glycol) in drug delivery:pros and cons as well as potential alternatives, Angew Chem., 49(36), 6288-6308.

Koç, M., Sakin, M., \& Kaymak-Ertekin, F., 2010, Mikroenkapsülasyon ve Gida Teknolojisinde Kullanımı, Pamukkale Üniversitesi Mühendislik Bilimleri Dergisi, 16(1), 77-86.

Kost, J. \& Langer, R., 2012, Responsive polymeric delivery systems, Adv. Drug Deliv. Rev., 64, 327-341.

Kozubek, A., Gubernator, J., Przeworska, E., \& Stasiuk, M., 2001, Liposomal drug delivery, a novel approach: PLARosomes, Acta Biochim. Pol., 47 (3), 639-649.

Kumar, R.M.N.V., 2000, Nano and microparticles as controlled drug delivery devices, J. Pharm. Pharm. Sci., 3 (2), 234 258.

Kumar, R.M.N.V., Bakowsky, U. \& Lehr, C.M., 2004, Preparation and characterization of cationic PLGA nanospheres as DNA carriers, Biomaterials, 25, 1771-1777.

Kwon, H.Y., Lee, J.Y., Choi, S.W., Jang, Y., \& Kim, J.H., 2001, Preparation of PLGA nanoparticles containing estrogen by emulsification-diffusion method, Colloids Surf. A, 182, 123-130.

Lam, C.X.F., Teoh, S.H. \& Hutmacher, D.W., 2007, Comparison of the degradation of polycaprolactone and polycaprolactone (b-tricalcium phosphate) scaffolds in alkaline medium, Polym Int, 56(6), 718-728.

Langer, R., 1993, Polymer-controlled drug delivery systems, American Chemical Society, 26, 10, 537-542.

Langer, R., 2001, Perspectives: drug delivery, Drugs on target Science, 293, 58-59.

Lee, S.J., Jeong, J.R., Shin, S.C., Kim, J.C., Chang, Y.H., Lee, K.H., \& Kim, J.D., 2005, Magnetic enhancement of iron oxide nanoparticles encapsulated with poly(d,1-lactide-coglycolide), Colloids Surf. A, 255, 19-25.

Legrand, P., Barratt, G., Mosqueira, V., Fessi, H., \& Devissaguet, J.D., 1999, Polymeric nanocapsules as drug delivery systems, A review. S. T. P., Pharma. Sci., 9, 411-418.

Li, M., Rouaud, O., \&Poncelet, D., 2008, Microencapsulation by solvent evaporation: State of the art for process engineering approaches, International Journal of Pharmaceutics, 363(12), 26-39.

Lian, T. \& Ho, R.J.Y., 2001, Trends and developments in liposome drug delivery systems, J. Pharmceut. Sci., 90 (6), 667-680.

Liu, K.L., Widjaja, E., Huang, Y., Ng, X.W., Loo, S.C.J., Boey, F.Y.C., \& Venkatraman, S.S., 2011, A new insight for an old system: protein-PEG colocalization in relation to protein release from PCL/PEG blends, Mol Pharm., 8(6), 21732182.

Liu, M. \& Frechet, J.M., 1999, Designing dendrimers for drug delivery, Pharm. Sci. Technol. Today 10, 393-401.

Mathiowitz, E. \& Langer, R., 1987, Polyanhydride microspheres as drug carriers I. Hot-melt microencapsulation, J. Control. Rel., 5 (1), 13-22.

Medina, O.P., Zhu, Y., \& Kairemo, K., 2004, Targeted liposomal drug delivery in cancer, Curr. Pharm. Des., 10 (24), 29812989.

Miller, R.E. \& Anderson, J.L., 1964, Encapsulation process and its products, US Patent, 3,155,590.

Mirakabad, F. S.T., Nejati-Koshki, K., Akbarzadeh, A., Yamchi, M.R., Milani, M., Zarghami, N., Zeighamian, V., Rahimzadeh, A., Alimohammadi, S., \& Hanifehpour, Y., 2014, PLGA-based nanoparticles as cancer drug delivery systems, Asian Pac J Cancer Prev., 15(2), 517-535.

Moghimi, S.M., Hunter, A.C., \& Murray, J.C., 2005, Nanomedicine: current status and future prospects, FASEB J., 19, 311-330.

Mu, L. \& Feng, S.S., 2003, A novel controlled release formulation for the anticancer drug paclitaxel (Taxol(R)): PLGA nanoparticles containing vitamin E TPGS, J Control Release, 86(1),33-48.

Nafee, N., Taetz, S., Schneider, M., Schaefer, U.F., \& Lehr, C.M., 2007, Chitosan-coated PLGA nanoparticles for DNA/RNA delivery: effect of the formulation parameters on complexation and transfection of antisense oligonucleotides, Nanomedicine, 3 (3), 173-183.

Nagavarma, B.V.N., Yadav, H.K.S., Ayaz, A., Vasudha, L.S., \& Shivakumar, H.G., 2012, Different techniques for preparation of polymeric nanoparticles- a review, Asian J Pharm Clin Res.,5(3), 16-23.

O'Donnell, P.B. \& McGinity, J.W., 1997, Preparation of microspheres by the solvent evaporation technique, Adv. Drug Deliv. Rev., 28 (1), 25-42.

Oshimura, M., Takasu, A., \& Nagata, K., 2009, Controlled ringopening polymerization of $\varepsilon$-caprolactone using polymersupported scandium trifluoromethanesulfonate in organic solvent and ionic liquids, Macromolecules, 42(8), 30863091.

Pantazis, P., Dimas, K., Wyche, J.H., Anant, S., Houchen, C.W., Panyam, J., \& Ramanujam, R.P., 2012, Preparation of siRNA-encapsulated PLGA nanoparticles for sustained release of siRNA and evaluation of encapsulation efficiency, Meth Mol Biol (Clifton NJ), 906, 311-319.

Paolino, D., Sinha, P., Fresta, M., \& Ferrari, M., 2006, Drug delivery systems, Encyclopedia of Medical Devices and Instrumentation.

Park, K., \& Mrsny, R.J., 2000, Bölüm 1, Controlled Drug Delivery: Present and Future, In Controlled Drug Delivery; ACS Symposium Series, American Chemical Society, Washington.

Prabha, S. \& Labhasetwar, V., 2004, Nanoparticle-mediated wild-type p53 gene delivery results in sustained antiproliferative activity in breast cancer cells, Mol. Pharmacol., 1, 211-219.

Raja, M.M., Lim, P. Q., Wong, Y. S., Xiong, G. M., Zhang, Y., Venkatraman, S., \& Huang, Y., 2019, Polymeric Nanomaterials: Methods of Preparation and Characterization, Nanocarriers for Drug Delivery, In: Mohapatra, S.S., Ranjan, S., Dasgupta, N., Mishra, R.K., 
Thomas, S.(ed.), Bölüm 18, Elsevier, New York, ISBN: 9780-12-814033-8, 557-653.

Ratnam, V.D., Ankola, D., Bhardwaj, V., Sahana, D.K., \& Ravi Kumar, M.N.V., 2006, Role of antioxidants in prophylaxis and therapy: a pharmaceutical perspective, J. Control. Rel., 113 (3), 189-207.

Risch, S.J. \& Reineccius, G.A., 1995, Encapsulation: overview of uses and techniques, Encapsulation and Controlled Release of Food Ingredients, Bölüm 1, American Chemical Society, Washington, 2-7.

Rivera, P.A., Martinez-Oharriz, M.C., Rubio, M., Irache, J.M., \& Espuelas, S., 2004, Fluconazole encapsulation in PLGA microspheres by spray-drying, J. Microencapsul., 21 (2), 203-211.

Rosca, I.D., Watari, F., \& Uo, M., 2004, Microparticle formation and its mechanism in single and double emulsion solvent evaporation, J. Control. Rel., 99 (2), 271-280.

Roullin, V.G., Deverre, J.R., Lemaire, L., Hindre', F., VenierJulienne, M.C., Vienet, R., \& Benoit, J.P., 2002, Anti-cancer drug diffusion within living rat brain tissue: an experimental study using [3H](6)-5-fluorouracil-loaded PLGA microspheres, Eur J Pharm Biopharm., 53(3), 293-299.

Sah, H., 1997, Microencapsulation techniques using ethyl acetate as a dispersed solvent: effects of its extraction rate on the characteristics of PLGA microspheres, J. Contr. Rel., 47, 233-245.

Sahoo, S.K. \& Labhasetwar, V., 2005, Enhanced antiproliferative activity of transferrin-conjugated paclitaxelloaded nanoparticles is mediated via sustained intracellular drug retention, Mol. Pharmacol., 2, 373-383.

Sahoo, S.K., Parveen, S., \& Panda, J.J., 2007, The present and future of nanotechnology in human health care, Nanomedicine, 3 (1), 20-31.

Seville, P.C., 2007, Spray-dried powders for pulmonary drug delivery, Crit. Rev. Therapeut. Drug Carrier Syst.,24 (4), 307-360.

Song, K.C., Lee, H.S., Choung, I.Y., Cho, K.I., Ahn, Y., \& Choi, E.J., 2006, The effect type of organic phase solvents on the particle size of poly(d,l-lactide-co-glycolide) nanoparticles, Colloids Surf. A, 276, 162-167.

Stevanović, M., 2017, Polymeric micro- and nanoparticles for controlled and targeted drug delivery, Nanostructures for Drug Delivery, In: Andronescu, E., Grumezescu, A.M.(ed.), Bölüm 11, Elsevier, New York, ISBN: 978-0-323-46143-6, 355-378.

Stevanovic', M. \& Uskokovic', D., 2009a, Poly(d,1-lactide-coglycolide) for controlled drug delivery of vitamins, Curr. Nanosci, 5 (1), 1-15.

Stevanovic', M. \& Uskokovic', D., 2009b, Influence of different degradation medium on release of ascorbic acid from poly(d,l-lactide-co-glycolide) nano- and microspheres, Russ. J. Phys. Chem. A, 83 (9), 1457-1460.

Stevanovic', M.M., Jordovic', B., \& Uskokovic', D.P., 2007a, Preparation and characterization of poly(d,1-lactide-coglycolide) nanoparticles containing ascorbic acid, J. Biomed. Biotechnol., 8.

Stevanovic', M., Savic', J., Jordovic', B., \& Uskokovic', D., $2007 b$, Fabrication, in vitro degradation and the release behaviours of poly(d,l-lactide-co-glycolide) nanospheres containing ascorbic acid, Colloids Surf. B, 59 (2), 215-223.

Stupar, P., Pavlovic', V., Nunic', J., Cundrič S., Filipič, M., \& Stevanovic', M., 2014, Development of lyophilized spherical particles of poly(epsilon-caprolactone) and examination of their morphology, cytocompatibility and influence on the formation of reactive oxygen species, J. Drug Deliv. Sci. Technol., 24 (2), 191-197.

Sumer, B. \& Gao, J., 2008, Theranostic nanomedicine for cancer, Nanomedicine, 3 (2), 137-140.

Takashima, Y., Saito, R., Nakajima, A., Oda, M., Kimura, A., Kanazawa, T., \& Okada, H., 2007, Spray-drying preparation of microparticles containing cationic PLGA nanospheres as gene carriers for avoiding aggregation of nanospheres, Int. J. Pharm., 343 (1-2), 262-269.

Tan, B.H., Muiruri, J.K., Li, Z., \& He, C., 2016, Recent progress in using stereocomplexation for enhancement of thermal and mechanical property of polylactide, ACS Sustainable Chem Eng., 4(10), 5370-5391.

Thomasin, C., Merkle, H.P., \& Gander, B., 1998a, Drug microencapsulation by PLA/PLGA coacervation in the light of thermodynamics. 2. Parameters determining microsphere formation, J. Pharmceut. Sci., 87 (3), 269-275.

Thomasin, C., Nam- Tran, H., Merkle, H.P., \& Gander, B., 1998b, Drug microencapsulation by PLA/PLGA coacervation in the light of thermodynamics. 1. Overview and theoretical considerations, J. Pharm. Sci., 87 (3), 259268.

Uddin, M.S., Hawlader, M.N.A., Zhu, H.J., 2001, Microencapsulation of ascorbic acid: effect of process variables on product characteristics, J. Microencapsul, 18 (2), 199-209.

Ulery, B.D., Nair, L.S., \& Laurencin, C.T., 2011, Biomedical applications of biodegradable Polymer, J Polym Sci B Polym Phys., 49(12), 832-864.

Vilar, G., Tulla-Puche, J., \& Albericio, F., 2012, Polymers and drug delivery systems, Curr. Drug. Deliv., 9(4), 367-394.

Wieland-Berghausen, S., Schote, U., Frey, M., \& Schmidt, F., 2002, Comparison of microencapsulation techniques for the water-soluble drugs nitenpyram and clomipramine $\mathrm{HCl}, \mathrm{J}$. Control. Rel., 85 (1-3), 35-43.

Wong, S.Y., Pelet, J.M., \& Putnam, D., 2007, Polymer systems for gene delivery-past, present and future, Prog. Polym. Sci., 32 (8-9), 799-837.

Woodruff, M.A. \& Hutmacher, D.W., 2010, The return of a forgotten polymer Polycaprolactone in the 21st century, Progress in Polymer Science, 35(10), 1217-1256.

Yalabik-Kas, H.S., 1983, Microencapsulation and in vitro dissolution of oxazepam from ethylcellulose microcapsules, Drug Dev. Ind. Pharm., 9 (6), 1047-1060.

Yilgor, P., Hasirci, N., \& Hasirci, V., 2010, Sequential BMP2/BMP-7 Delivery from Polyester Nanocapsules, Journal of Biomedical Materials Research Part A, 93(2), 528-536.

Yoo, H.S., 2006, Preparation of biodegradable polymeric hollow microspheres using $\mathrm{O} / \mathrm{O} / \mathrm{W}$ emulsion stabilized by Labrafil, Colloids Surf. B, 52, 47-51.

Yoshiyuki, K., Hirata, G., \& Samejima, M., 1983, Studies on microcapsules II: influence of molecular weight of ethylcellulose in the microencapsulation of ascorbic acid, Chem. Pharmaceut. Bull., 31, 4476-4482.

Zuidam, N.J. \& Nedovic, V., 2010, Overview of Microencapsulates for Use in Food Products or Processes and Methods to Make Them, Encapsulation Technologies for Active Food Ingredients and Food Processing, In: Zuidam, N.J. ve Shimoni, E. (ed.), Bölüm 2, Springer, New York, ISBN: 978-1-4419-1008-0, 3-29. 